\title{
Effect of age on the thickness of adult articular cartilage at the shoulder joint
}

\author{
G. MEACHIM \\ Department of Pathology, University of Liverpool
}

Human articular cartilage can develop areas of fibrillation. In such areas there is fraying and splitting of the cartilage, frequently accompanied by its local disintegration and erosion. Collins (1949) regarded all grades of fibrillation as forms of 'osteoarthritic' cartilage change, although he recognized that many of the destructive lesions found at necropsy are mild and appear to have been clinically asymptomatic.

In man, areas of cartilage fibrillation become commoner and severer with increasing age (Heine, 1926), but in each age group there is variation from person to person, from joint to joint (Collins and Meachim, 1961), and from area to area within an affected joint (Collins, 1949; Goodfellow and Bullough, 1967). Thus, although cartilage fibrillation is age-correlated, it is basically a focal process and local factors must be at least partly responsible for its development (Meachim, 1969). It is relevant to enquire if adult articular cartilage also undergoes a generalized age-change of a nature which predisposes to fibrillation. In investigating this possibility it is necessary to distinguish between age changes during adult life and changes attributable to cartilage maturation during the period of skeletal growth (Meachim, 1969). When analysing the results, fibrillated and non-fibrillated specimens require separate consideration, since fibrillation is in itself associated with changes in the physical and chemical properties of the cartilage (Lindahl, 1958; Bollet and Nance, 1966; Freeman, Swanson, and Kempson, 1969; Mankin and Lippiello, 1970).

The present study concerns the effect of ageing and of mild superficial fibrillation on the thickness of the uncalcified part of adult human articular cartilage. The study was made on cartilage from the upper end of the humerus: this articular cartilage often remains free from fibrillation even in the age group 65 to 84 years (Collins and Meachim, 1961). Because cartilage thickness can vary between different sites in the same joint, the specimens were all taken from the central part of the articular surface.

\section{Material and methods}

The specimens were obtained at necropsy from 42 subjects ( 22 men; 20 women) whose ages ranged from 25 to 82 years. The left shoulder joint was arbitrarily selected for study. After opening the joint and noting the state of the articular surface as seen with the naked-eye, a central transverse block of humeral articular cartilage with underlying bone was taken for histology. Joints with evidence of rheumatoid disease were excluded.

The tissue was fixed in formol saline and decalcified by EDTA (ethylene diamine tetra-acetic acid). Paraffin sections were cut at right angles to the plane of the joint surface and stained with Mayer's haematoxylin. The sections were examined with the light microscope to determine whether or not the articular surface of the cartilage was fibrillated; specimens with deep fibrillation were not included in the study. A point-counting method was then used on the histological preparations to determine the total area in transverse section of the uncalcified cartilage overlying a measured length along the boundary between the uncalcified tissue and the calcified zone. The thickness of the uncalcified cartilage was then calculated by taking the value obtained for area and dividing this by width as measured along the boundary with the calcified zone. Thus the thickness measurements obtained represent the average depth of uncalcified cartilage beneath the central part of the humeral articular surface of the shoulder joint. The method described was used in preference to direct measurements of cartilage thickness, since it is less likely to be affected by minor fluctuations within the section of contours at the articular surface and at the boundary with the calcified zone.

\section{Results}

NON-FIBRILLATED CARTILAGES

In 32 subjects the articular cartilage from the upper end of the humerus showed no evidence of fibrillation, as determined by naked-eye and histological examination. In these subjects the thickness of uncalcified cartilage at the central part of the joint surface ranged from 0.8 to $1.9 \mathrm{~mm}$. (mean 1.45). The mean of the sixteen specimens from men was not significantly different $(P<0.2>0.1)$ from 
the mean for the sixteen specimens from women (Table 1)

Table I Thickness of non-fibrillated articular cartilage from upper end of humerus, by sex

\begin{tabular}{|c|c|c|c|c|}
\hline \multirow[t]{2}{*}{ Sex } & \multirow[t]{2}{*}{$\begin{array}{l}\text { Age range } \\
\text { (yrs) }\end{array}$} & \multirow[t]{2}{*}{$\begin{array}{l}\text { No. of } \\
\text { subjects }\end{array}$} & \multicolumn{2}{|c|}{$\begin{array}{l}\text { Thickness uncalcified } \\
(\mathrm{mm} .)\end{array}$} \\
\hline & & & Mean & Range \\
\hline $\begin{array}{l}\text { Male } \\
\text { Female }\end{array}$ & $\begin{array}{l}25-75 \\
30-74\end{array}$ & $\begin{array}{l}16 \\
16\end{array}$ & $\begin{array}{l}1 \cdot 39 \\
1 \cdot 52\end{array}$ & $\begin{array}{l}0 \cdot 8-1 \cdot 9 \\
1 \cdot 2-1 \cdot 9\end{array}$ \\
\hline
\end{tabular}

Cartilage thickness in males compared with cartilage thickness in females $P<0.2>0 \cdot 1$.

When both sexes were considered together, the mean of the uncalcified thickness of the nonfibrillated cartilages was $1.48 \mathrm{~mm}$. in fourteen subjects ranging in age from 25 to 53 years and 1.43 $\mathrm{mm}$. in eighteen subjects ranging in age from 59 to 75 years (Table II). Statistical analysis performed separately on the data from men and from women (Table III) confirmed that there was no significant difference in non-fibrillated cartilage thickness

Table II Thickness of non-fibrillated articular cartilage from upper end of humerus in younger and older subjects compared

\begin{tabular}{|c|c|c|c|}
\hline \multirow{2}{*}{$\begin{array}{l}\text { Age range } \\
\text { (yrs) }\end{array}$} & \multirow{2}{*}{$\begin{array}{l}\text { No. of } \\
\text { subjects }\end{array}$} & \multicolumn{2}{|c|}{ Thickness uncalcified ( $\mathrm{mm}$ ) } \\
\hline & & Mean & Range \\
\hline $\begin{array}{l}25-53 \\
59-75\end{array}$ & $\begin{array}{l}14 \\
18\end{array}$ & $\begin{array}{l}1 \cdot 48 \\
1 \cdot 43\end{array}$ & $\begin{array}{l}1 \cdot 2-1 \cdot 9 \\
0 \cdot 8-1 \cdot 9\end{array}$ \\
\hline
\end{tabular}

Table III Thickness of non-fibrillated articular cartilage from upper end of humerus, by age and sex

\begin{tabular}{|c|c|c|c|c|}
\hline \multirow[t]{2}{*}{ Sex } & \multirow[t]{2}{*}{$\begin{array}{l}\text { Age range } \\
\text { (yrs) }\end{array}$} & \multirow[t]{2}{*}{$\begin{array}{l}\text { No. of } \\
\text { subjects }\end{array}$} & \multicolumn{2}{|c|}{$\begin{array}{l}\text { Thickness uncalcified } \\
(\mathrm{mm} .)\end{array}$} \\
\hline & & & Mean & Range \\
\hline \multirow[t]{2}{*}{ Male } & $25-53$ & 7 & $1 \cdot 43$ & $1 \cdot 2-1 \cdot 8$ \\
\hline & $59-75$ & 9 & $1 \cdot 36$ & $0 \cdot 8-1 \cdot 9$ \\
\hline \multirow[t]{2}{*}{ Female } & $30-53$ & 7 & $1 \cdot 53$ & $1 \cdot 2-1 \cdot 9$ \\
\hline & $59-74$ & 9 & $1 \cdot 52$ & $1 \cdot 3-1 \cdot 8$ \\
\hline $\begin{array}{l}\mathbf{P}<0.9>0 \\
\text { Cartilage } \\
\text { females } \mathbf{P} \\
\text { Cartilage } \\
\mathbf{P}<0.3>0\end{array}$ & $\begin{array}{l}\text { ckness in youn } \\
\text { hickness in } \\
\text { hickness in } \\
\text { hick } \\
\text { lickness in of }\end{array}$ & $\begin{array}{l}\text { ger compare } \\
\text { younger c } \\
\text { younger m } \\
\text { lder males }\end{array}$ & $\begin{array}{l}\text { ith old } \\
\text { pared } \\
\text { com }\end{array}$ & $\begin{array}{l}\text { es } P<0.7>0 \\
\text { older femal } \\
\text { with young } \\
\text { older femal }\end{array}$ \\
\hline
\end{tabular}

between the older and the younger subjects $(P<$ $0.7>0.6$ for the men; $P<0.9>0.8$ for the women). In keeping with this result, no trend was apparent when the cartilage thickness measurement was plotted against age for each of the subjects studied; it was also found that the mean values from three consecutive age periods ( 25 to $44 ; 45$ to 64 : 65 to 75 years) were of a similar order (Table IV).

Table IV Thickness of non-fibrillated articular cartilage from upper end of humerus in three consecutive age groups

\begin{tabular}{llll}
\hline $\begin{array}{l}\text { Age range } \\
(y r s)\end{array}$ & $\begin{array}{l}\text { No. of } \\
\text { subjects }\end{array}$ & \multicolumn{1}{l}{ Thickness uncalcified $(\mathrm{mm})}$. \\
\cline { 3 - 4 } & & Mean & Range \\
\cline { 3 - 3 } $25-44$ & 9 & $1 \cdot 48$ & $1 \cdot 2-1 \cdot 9$ \\
$45-64$ & 13 & $1 \cdot 42$ & $0 \cdot 8-1 \cdot 7$ \\
$65-75$ & 10 & $1 \cdot 47$ & $1 \cdot 2-1 \cdot 9$ \\
\hline
\end{tabular}

\section{MILD SUPERFICIAL FIBRILLATION}

In ten of the subjects (6 men; 4 women) histological examination showed fraying and splitting of the humeral articular surface, without overt erosion or deep fibrillation of the cartilage. Three of these subjects were aged 36,39 , and 52 years respectively; the other seven were in the age range 61 to 82 years. The mean of the uncalcified thickness of these ten cartilages with mild superficial fibrillation was 1.69 $\mathrm{mm}$. (range $1 \cdot 3$ to $2 \cdot 2 \mathrm{~mm}$.) compared with a mean of $1.45 \mathrm{~mm}$. (range 0.8 to $1.9 \mathrm{~mm}$.) in the 32 nonfibrillated samples (Table V). This result suggests that in the shoulder joint superficial fibrillation does not develop as a consequence of thinning of the humeral cartilage. Thus the mean of the thickness of the cartilages with mild superficial fibrillation was in fact slightly greater than that of the non-fibrillated samples; this difference was statistically significant

Table $\mathbf{V}$ Thickness of articular cartilage from upper end of humerus in non-fibrillated specimens compared with specimens showing mild superficial fibrillation

\begin{tabular}{|c|c|c|c|c|}
\hline \multirow[t]{2}{*}{ Specimen } & \multirow[t]{2}{*}{$\begin{array}{l}\text { Age range } \\
\text { (yrs) }\end{array}$} & \multirow[t]{2}{*}{$\begin{array}{l}\text { No. of } \\
\text { subjects }\end{array}$} & \multicolumn{2}{|c|}{$\begin{array}{l}\text { Thickness uncalcified } \\
\text { (mm.) }\end{array}$} \\
\hline & & & Mean & Range \\
\hline \multirow{2}{*}{$\begin{array}{l}\text { Non- } \\
\text { fibrillated } \\
\text { Superficial } \\
\text { fibrillation }\end{array}$} & $25-75$ & 32 & $1 \cdot 45$ & $0.8-1.9$ \\
\hline & $36-82$ & 10 & $1 \cdot 69$ & $1 \cdot 3-2 \cdot 2$ \\
\hline
\end{tabular}

Cartilage thickness in non-fibrillated specimens compared with thickness in specimens showing mild superficial fibrillation $P<0.02>0.01$. 
in the data available $(P<0.02>0.01)$, although the overlapping range of the individual values in the two groups should be noted.

\section{Discussion}

The measurements of uncalcified cartilage thickness were made on histological sections of tissue obtained at necropsy and fixed in formalin, and they do not take into account possible changes in the volume of the fresh cartilage which might occur after death and during tissue fixation. However, in the case of the non-fibrillated specimens, it seems unlikely that such changes could have masked an effect of ageing on cartilage thickness, especially since Linn and Sokoloff (1965) have shown that ageing during adult life produces no change in the total or expressible fluid content of human articular cartilage. From the present study it is, therefore, concluded that age has no appreciable effect on the thickness of nonfibrillated articular cartilage at the upper end of the adult humerus. Previous studies of adult human articular cartilage from this site have shown that age also has no appreciable effect on the cell-density of the uncalcified tissue (Meachim and Collins, 1962) and on the amount of sulphate fixed by the chondrocytes in vitro (Collins and Meachim, 1961). Taken together, the previous findings and those of the present study suggest that ageing during adult life does not significantly impair the ability of the cell population to manufacture and maintain the matrix of upper humeral articular cartilage. This conclusion is in line with the results of other investigations of adult human articular cartilage, which have so far revealed surprisingly little evidence of a generalized change with age in the total mucopolysaccharide content, in the chondroitin sulphate content and chain length, in the concentration of compounds containing neutral sugar, and in the ash content of non-fibrillated samples (Anderson, Ludowieg, Harper, and Engleman, 1964; Bollet and Nance, 1966). Similarly, there is no significant change during adult life in the overall cellularity of intact femoral cartilage from the human knee (Stockwell, 1967).

The present observations do not support the view that superficial fibrillation in the shoulder joint develops as a consequence of thinning of the articular cartilage, since the mean of the thickness of the humeral cartilages with mild superficial fibrillation was slightly greater than that of the non-fibrillated specimens after fixation. It must be emphasized that the fibrillation was confined to fraying and splitting at the articular surface, without overt erosion of the tissue. The reason for the apparent increase $(P<0.02>0.01)$ in thickness in these fibrillated cartilages is not clear and one cannot exclude the possibility that the finding is due merely to a difference between fibrillated and non-fibrillated samples in volume change during fixation, particularly since fibrillation is known to be associated with an increase in the water content of the tissue (Lindahl 1958). In a study with the electron microscope, Meachim and Roy (1969) observed that ultrastructural changes of 'mild fibrillation' are associated sometimes with an abnormally wide separation of collagen fibres beneath the articular surface, but it is uncertain whether or not this localized separation of fibres would appreciably affect the total thickness of the cartilage.

\section{Summary}

A study has been made of the effect of age and of mild superficial fibrillation on the thickness of adult human articular cartilage obtained at necropsy from the central part of the joint surface at the upper end of the humerus. The depth of uncalcified cartilage at this site was measured in $\mathbf{4 2}$ subjects whose ages ranged from 25 to 82 years, using a point-counting technique on histological sections of fixed tissue. In 32 of the specimens there was no evidence of fibrillation, as determined by naked-eye and histological examination: age had no significant effect on the thickness of the uncalcified cartilage in these specimens. In the other ten specimens the cartilage showed mild superficial fibrillation: the findings in these specimens did not support the view that fibrillation in the adult shoulder joint develops as a consequence of thinning of the humeral cartilage.

The help of Dr. P. Hasleton with the statistical analysis is gratefully acknowledged.

\section{References}

Anderson, C. E., Ludowieg, J., Harper, H. A., and Engleman, E. P. (1964) J. Bone Jt Surg., 46A, 1176 (The composition of the organic component of human articular cartilage).

BOLLET, A. J., AND NANCE, J. L. (1966) J. clin. Invest., 45, 1170 (Biochemical findings in normal and osteoarthritic articular cartilage. II. Chondroitin sulfate concentration and chain length, water, and ash content).

Collins, D. H. (1949) 'The Pathology of Articular and Spinal Diseases,' pp. 74-115. Arnold, London.

AND MEACHIM, G. (1961) Ann. rheum. Dis., 20, 117 (Sulphate $\left({ }^{35} \mathrm{SO}_{4}\right)$ fixation by human articular cartilage compared in the knee and shoulder joints).

Freeman, M. A. R., Swanson, S. A. V., AND Kempson, G. E. (1969) 'Orthopödischer Gemeinschaftskongress.' Deutsche Gesellschaft für Orthopädie und Traumatologie and British Orthopaedic Association (7-9 June, 1968, Wiesbaden). Enke, Stuttgart. Bücherei des Orthopäden, 4, 37 (Mechanical abnormalities in some visually normal cartilage). 
Goodfellow, J. W., AND Bullough, P. G. (1967) J. Bone Jt Surg., 49B, 175 (The pattern of ageing of the articular cartilage of the elbow joint).

HeINE, J. (1926) Virchows Arch. path. Anat., 260, 521 (Über die Arthritis deformans).

LINDAHL, O. (1958) Acta orthop. scand. 17, 134 (Über den Wassergehalt des Knorpels).

LINN, F. C., AND SoKoloff, L. (1965) Arthr. and Rheum., 8, 481 (Movement and composition of interstitial fluid of cartilage).

Mankin, H. J., AND Lippiello, L. (1970) J. Bone Jt Surg., 52A, 424 (Biochemical and metabolic abnormalities in articular cartilage from osteo-arthritic human hips).

Меаснім, G. (1969) Clin. Orthop., 64, 33 (Age changes in articular cartilage).

- AND Coluns, D. H. (1962) Ann. rheum. Dis., 21, 45 (Cell counts of normal and osteo-arthritic articular cartilage in relation to the uptake of sulphate $\left({ }^{35} \mathrm{SO}_{4}\right)$ in vitro).

— AND Roy, S. (1969) J. Bone Jt Surg., 51B, 529 (Surface ultrastructure of mature adult human articular cartilage).

StockWell, R. A. (1967) J. Anat. (Lond.), 101, 753 (The cell density of human articular and costal cartilage). 